\title{
Calculation and Analysis of Synergy Potential of Exhibition Economy in the PRD Urban Agglomerations
}

\author{
Peng Li, Yiqing Lv*, Dan Yao \\ Shenzhen Tourism College of Jinan University, Shenzhen, China \\ Email: *lv_yq@sz.jnu.edu.cn, ya odan.sztc@gmail.com
}

How to cite this paper: Li, P., Lv, Y.Q. and Yao, D. (2017) Calculation and Analysis of Synergy Potential of Exhibition Economy in the PRD Urban Agglomerations. Modern Economy, 8, 1580-1593. https://doi.org/10.4236/me.2017.812105

Received: November 13, 2017

Accepted: December 22, 2017

Published: December 25, 2017

Copyright $(9) 2017$ by authors and Scientific Research Publishing Inc. This work is licensed under the Creative Commons Attribution International License (CC BY 4.0).

http://creativecommons.org/licenses/by/4.0/

\section{cc) (i) Open Access}

\begin{abstract}
This paper takes the PRD (Pearl River Delta) urban agglomeration as the research object and improves the gravity models to estimate and analyze synergetic development potential of exhibition economy in eight major PRD cities. Firstly, it makes a factual analysis of the overall development trends and characteristics of exhibition economy in China, and introduces the development status of exhibition economy in the PRD Economic Circle. Secondly, it constructs indicator systems for the development evaluation of exhibition economy and evaluates comprehensive development capacity of exhibition economy in the eight PRD cities. Thirdly, gravity models are improved to calculate the synergetic development potential of exhibition economy in the eight PRD cities. Research Results: The PRD Economic Circle consists of three parts, namely, Guang-Fo-Zhao Economic Circle, Shenzhen-Dongguan-Huizhou Economic Circle and Zhuhai-Zhongshan-Jiangmen Economic Circle. Wherein, Guang-Fo-Zhao Economic Circle is centered on Guangzhou while Shenzhen-Dongguan-Huizhou Economic Circle and Zhuhai-Zhongshan-Jiangmen Economic Circle are centered on Shenzhen. Research Proposals: The local government should establish administrative departments for the synergetic development of exhibition economy in the PRD urban agglomeration, rationalize the allocation of exhibition economic resources, optimize synergetic development structures of exhibition economy, explore characteristic images of cities and integrate them into the PRD Economic Circle; promote synergetic development of exhibition economy in the PRD urban agglomeration, thereby enhancing domestic and international competitiveness of the exhibition industry and driving robust growth of regional economy. Innovations of the paper are described below: it studies synergetic development of exhibition economy in the PRD urban agglomeration for the first time, explores the integration of exhibition economy in urban agglomerations of different levels,
\end{abstract}


seeks solutions for the common development of exhibition economy in urban agglomerations and makes strategic planning for the development of exhibition economy in the PRD urban agglomeration. Currently, there are few researches on the synergetic development of exhibition economy in urban agglomerations of China.

\section{Keywords}

Exhibition Economy, Synergy Potential, PRD Urban Agglomeration, Gravity Model

\section{Introduction}

In the modern society, exhibition economy has acquired an increasingly prominent position. Although it has a late start in China, the emerging tertiary industry which has developed rapidly in recent years has far exceeded the tertiary industry in respect to its influence. Compared with the traditional service industry, it involves the primary industry and the secondary industry and prompts economic development of industries like construction, transportation, tourism and hospitalization, with a driving coefficient of 1:8. Therefore, it can be assumed as one of the major economic pillars of the country. The PRD region is one of the earliest regions implementing the reform and opening-up policy in China. Besides, it is also one of the most important areas to develop urban agglomeration economy. China has adopted synergetic development of exhibition economy in the PRD region as a long-term national strategy since the end of 2008, which has already made some achievements in economic, social and cultural aspects. Since the correlation and resource advantages of exhibition industry vary from city to city, it is feasible to enhance and optimize synergetic development mechanisms of economy in urban agglomerations by starting from the development of the exhibition industry. Based on this, this paper takes exhibition economy in the RPD urban agglomerations as the research object and attempts to seek breakthroughs for synergetic development of exhibition economy in the PRD region and hence to optimize the synergetic development mechanisms and boost the development of exhibition economy in this region.

The exhibition industry is an emerging service industry that differs from traditional service industry in development characteristics and classification. Up to now, considerable studies have been made by scholars both at home and abroad on the exhibition industry, both theoretically and practically. Wherein, foreign researches on exhibition economy involve lots of disciplines, which are mainly embodied in the research methods of regional economy and metropolitan economy. As a weapon to improve comprehensive competitiveness of cities, exhibition economy is of great economic value to the exploration of synergy potential of exhibition economy in urban agglomerations. Australian scholar Johnny [1] believes that the exhibition industry belongs to the activity industry 
and has close relation to it. American scholar Harsher E. Cherk [2] argues that other industries serve as supporters for the development of the exhibition industry. In addition, the development of the exhibition industry relies intensively over the support of enterprises, citizens and local governments. To evaluate the benefits of exhibitions, it is necessary to evaluate the general benefits over the local economy, politics, society and culture. According to Teigland [3], exhibition economy exerts positive impact over the local residents. They raise positive attitudes towards exhibitions, thereby improving accessibility and attractiveness of exhibition venues and increasing corresponding benefits. In China, both exhibition industry and exhibition economy developed rather late. However, scholars still have achieved fruitful research results. Wang Baolun [4] points out that exhibition tourism means earning economic benefits by providing exhibition venues and organizing tourism related activities. Chen Laisheng [5] promotes that China implemented planned economy for thirty years after its foundation. Under the planned economic system, only several exhibitions and cultural activities were organized and held by national governments. Technically, there was no exhibition economy. In 1957 when the Sino-Soviet relations got frosty, China held the Guangzhou Export Commodities Fair, namely, the first export commodities fair, to break economic barriers imposed by western countries. He Jianying [6] believes that exhibition tourism is a kind of tourism that attracts visitors through exhibition and then meet the interpersonal needs of people. Based on industrial cluster theories and general theories of exhibition, Zhang Juan [7] made a detailed study regarding the relations between the exhibition industry and other industries in accordance with the development status of the PRD exhibition economy, thereby revealing fundamental reasons influencing exhibition economy development in this region. Hu Ping [8] argues that exhibition economy can greatly stimulate the development of other industries. Through the study of Shanghai New International Expo, it has been found that the driving coefficient of exhibitions reaches 1:8.4, approaching to the international level. With the Yangtze River Delta metropolitan area as the research scope, $\mathrm{Li} \mathrm{Lu}$ and Ji Jianhua [9] explore the methods of defining metropolitan areas. Sun Qin [10] analyzes the World Expo and discovers that exhibitions play an important role in promoting Shanghai economy. Zhang Jun [11] discusses layout of exhibition development in Shanghai and explores the development modes and coverage of exhibition economy in this city. Huang Qiubo [12] quantitatively analyzes the influence of the exhibition industry on related industries in Hangzhou. Meanwhile, he also made a study about the correlation between exhibition, business and tourism. Also, a quantitative study about the relations between total tourism input and consumable retail sales simulated by the exhibition industry has been made. Tang Yan [13] defines regional cooperation between metropolises as the cooperation between relevant governments, individuals, agencies and nonprofit organizations to deal with the problems of common concern and also to realize the common objectives or to achieve specific purposes. Jiang Manqi [14] believes 
that urban agglomerations are spatial forms of city-intensive areas with multiple core groups. Jointly influenced by environments and markets, cities strive to realize urban agglomeration integration by virtue of political, economic and social competition and cooperation during the process of regional urbanization, which is referred to as synergetic development of urban agglomerations [15]. Liu Wei [16] studies the exhibition industry in Beijing, Tianjin and Hebei, making an analysis about the development status of the exhibition industry in this region and offers reliable suggestions for future development of exhibition economy.

To sum up, although domestic scholars have made great contributions to the researches on exhibition economy, quantitative researches on exhibition economy need to be further developed. Judging from the current researches, scholars mostly analyze influencing factors on the development of regional exhibition economy, without studying exhibition economy from the perspective of synergetic development of urban agglomerations. With the formation of the regional economic development strategy in China, it has become increasingly important to study synergetic development of exhibition economy from the perspective of urban agglomerations. However, there are few researches on the calculation and integration of synergetic development potential of exhibition economy in urban agglomerations, especially in the PRD urban agglomeration. By virtue of qualitative and quantitative analysis, this paper explores synergetic development features and trends of exhibition economy in the PRD urban agglomeration and methods of constructing urban agglomerations with balanced economic development. Innovations of the paper are described below: it studies synergetic development of exhibition economy in the PRD urban agglomeration for the first time, explores the integration of exhibition economy in urban agglomerations of different levels, seeks solutions for the common development of exhibition economy in urban agglomerations and makes strategic planning for the development of exhibition economy in the PRD urban agglomeration. Currently, there are few researches on the synergetic development of exhibition economy in urban agglomerations China.

\section{Present Status of Exhibition Economy in China and the PRD Region}

\subsection{Overall Development Status and Characteristics of Exhibition Economy}

Although exhibition economy in the underdeveloped country had a late start, Chinese exhibition economy has its own advantages. Firstly, exhibition economy is developing rapidly in China. According to the Statistical Reports on Exhibitions in China, during the period from 2011 to 2015, the number of exhibitions in China increased from 8160 to 11,798 (increase by $26.6 \%$ ) while the exhibition area rose from $73,300,000 \mathrm{~m}^{2}$ to $92,830,000 \mathrm{~m}^{2}$ (increase by 44.6\%) from 2011 to 2015. China has the largest exhibition area in the world. From 2013 to 2015, the number of exhibitions increased from 4905 to 6176. In addition, the number of 
professional exhibition venues increased from 226 to 286 in one year, with a growth rate of $26.5 \%$. These figures serve as the best indexes illustrating the rapid development and urban investment in the exhibition industry in China. Secondly, exhibitions in China are diversified and high value-added, involving fields like clothing, furniture, food, smart appliance, aviation and robot. The exhibits are quite delicate and professional in order to meet the needs of different visitors. The target audiences are diversified. In addition to traditional exhibitions for business visitors, tourism exhibitions are held to expand target audiences. For example, many exhibitions are held in the golden week or short holidays to make it more convenient for tourists to come to the local exhibitions when they travel. This is also for the own good of the exhibition. Such diversified development model not only involves more citizens into exhibitions, but also maximizes the value of the exhibitions. Thirdly, exhibition economic circles have come into being under urban economic circles. Exhibition economy in China mainly concentrates in economic circles centered on super first-tier cities. For example, the Beijing-Tianjin-Hebei Economic Circle is centered on Beijing, the PRD Economic Circle is centered on Guangzhou while the Yangtze River Delta Economic Circle is centered on Shanghai. As the political center of China, Beijing enjoys great advantages in holding exhibitions. The 2008 Olympic Games took place in Beijing, which is definitely a significant chapter in the exhibition history. As for the center of the Yangtze River Delta Economic Circle, Shanghai ranked first in China in 2015 in respect to its exhibition areas $\left(15,115,500 \mathrm{~m}^{2}\right)$. Guangzhou, the leader of the PRD region, had an exhibition area of 8,617,000 $\mathrm{m}^{2}$ and held a total of 482 exhibitions in 2015. It ranked second in China in respect to the exhibition areas. In addition to economic circles centered on super first-tier cities, many first-tier cities in China are developing rapidly and gradually catching up with and even surpassing these super first tier cities. For instance, Chongqing ranked third for an exhibition area of 7,023,000 $\mathrm{m}^{2}$. However, there are many problems in the development of exhibition economy in China. Due to the late start and the imperfect exhibition enterprise management systems, most exhibition enterprises are still in their infancy in respect to the management, being in a disadvantaged position compared with the international renowned exhibition enterprises. Therefore, this paper focuses on how to improve synergies of exhibition economy and enhance its comprehensive competiveness by virtue of urban agglomerations.

\subsection{Development Status of Exhibition Economy in the PRD Urban Agglomerations}

As one of the three major regional economic circles in China, the PRD Economic Circle has achieved remarkable development in exhibition economy. Guangzhou is internationally renowned for the Guangzhou Export Commodities Fair; Shenzhen is credited for high-tech exhibitions; Zhuhai Aviation \& Aerospace Exhibition is the only aviation and aerospace exhibition in China. In addition, 
there are garment exhibitions in Humen, ceramic fairs in Foshan, leather goods exhibitions in Huadu and digital fairs in Huizhou. Indeed, all of these exhibitions have greatly stimulated the economic development in the local places. However, their influence and radiation effect still needs to be further improved. The PRD Economic Circle has lots of exhibition halls and each exhibition hall covers a large area. Pazhou International Exhibition Center, covers an area of $700,000 \mathrm{~m}^{2}$, making it the largest exhibition center in China and Asia. Shenzhen Convention \& Exhibition Center covers an area of $280,000 \mathrm{~m}^{2}$, with the total investment of 3,200,000,000 RMB. Wherein, the exhibition for high-tech achievements covers an area of $40,000 \mathrm{~m}^{2}$. Upon completion, these large-scale and high-quality venues will further lead the PRD region to the world and meanwhile boost economic growth in this region.

With the rise of the exhibition industry in China, many areas have blindly followed the suit and the PRD region is no exception. Driven by short term profits, PRD region holds exhibitions blindly. However, many exhibitions share the same theme, thereby lacking characteristics and failing to develop healthily or sustainably. Therefore, it is of great significance to comprehensively analyze synergetic development of exhibition economy in the PRD urban agglomerations.

\section{Ranking of Exhibition Cities in the PRD Region}

In order to measure and calculate the ranking of exhibition cities, the research determines exhibition development levels from the perspective of microscopic data. The paper ranks exhibition economy of 9 monomer cities in the PRD urban agglomerations, establishes measurement indicator systems for exhibition economy development on the basis of exiting documents. There are altogether 14 indicators being set, including the number of exhibition halls (A); exhibition area (B); number of practitioners in the wholesale and retail industry (C); number of exhibition organizers (D); exhibition and business (E); passenger person-kilometers (F); tourism $(\mathrm{G})$; urban economic level $(\mathrm{H})$; number of hotels $(\mathrm{I})$; resident population $(\mathrm{J})$; transportation $(\mathrm{P})$; government attention $(\mathrm{L})$; urban natural environment $(\mathrm{M})$. In terms of the indicator weights, they are determined on the basis of questionnaires and AHP results (see Table 1). The data comes from 2015 Statistical Reports on Exhibitions in China and Guangdong Statistical Yearbook 2016.

According to Table 1, exhibition economy of a city relies intensively over the number of exhibition halls, exhibition area, number of exhibitions, number of exhibition organizers and number of practitioners in the wholesale and retail industry. Weights of these indicators are 10.17\%, 9.88\%, 9.98\%, 9.48\% and $9.68 \%$ respectively. Function indexes of the 14 indicators can be obtained according to the formula $K X_{i}=\frac{X_{i}}{\frac{1}{N} \sum_{i}^{N} X_{I}} K X_{i}=\frac{X_{i}}{\frac{1}{N} \sum_{i}^{N} X_{i}}$, In the formula, $X_{i}$ represents indicator value while $N$ represents different cities. Based on the function indexes, the composite index can be obtained. The calculation formula of 
Table 1. Mean values and weights of the indicator samples.

\begin{tabular}{|c|c|c|c|c|}
\hline No. & Var. & Var. Definition & Sample Average Val. & Weight Val. \\
\hline A & $\begin{array}{l}\text { Number of } \\
\text { Pavilions }\end{array}$ & $\begin{array}{l}\text { The specific number of } \\
\text { pavilions }\end{array}$ & 9.32 & $10.17 \%$ \\
\hline B & $\begin{array}{l}\text { Acreage of the } \\
\text { Pavilions }\end{array}$ & $\begin{array}{l}\text { The total exhibition area of } \\
\text { the exhibition hall }\end{array}$ & 9.06 & $9.88 \%$ \\
\hline $\mathrm{C}$ & $\begin{array}{l}\text { Number of } \\
\text { Exhibitions }\end{array}$ & $\begin{array}{c}\text { The number of exhibitions } \\
\text { held every year }\end{array}$ & 9.15 & $9.98 \%$ \\
\hline $\mathrm{D}$ & $\begin{array}{l}\text { Practitioners } \\
\text { (Wholesale \& } \\
\text { Retail) }\end{array}$ & $\begin{array}{c}\text { The number of } \\
\text { practitioners in both } \\
\text { industries }\end{array}$ & 3.24 & $3.53 \%$ \\
\hline $\mathbf{E}$ & $\begin{array}{l}\text { Number of } \\
\text { Exhibition } \\
\text { Organizations }\end{array}$ & $\begin{array}{l}\text { Number of organization of } \\
\text { exhibition organization }\end{array}$ & 8.69 & $9.48 \%$ \\
\hline F & $\begin{array}{l}\text { Exhibition \& } \\
\text { Business }\end{array}$ & $\begin{array}{l}\text { The number of } \\
\text { practitioners in the } \\
\text { industry related to the } \\
\text { exhibition }\end{array}$ & 8.87 & $9.68 \%$ \\
\hline G & $\begin{array}{c}\text { Resident } \\
\text { Population Size }\end{array}$ & Permanent residents & 3.63 & $3.96 \%$ \\
\hline $\mathrm{H}$ & $\begin{array}{l}\text { Passenger } \\
\text { Turnover }\end{array}$ & $\begin{array}{l}\text { The number of passengers } \\
\text { per unit time and the } \\
\text { average distance of the } \\
\text { product }\end{array}$ & 4.25 & $4.64 \%$ \\
\hline I & $\begin{array}{c}\text { Tourist } \\
\text { Accommodation } \\
\text { Rate }\end{array}$ & $\begin{array}{l}\text { Number of people } \\
\text { traveling for the night }\end{array}$ & 5.21 & $5.68 \%$ \\
\hline $\mathrm{J}$ & $\begin{array}{l}\text { Urban Economic } \\
\text { Level }\end{array}$ & Per capita GDP & 8.13 & $8.87 \%$ \\
\hline $\mathrm{K}$ & Number of Hotels & $\begin{array}{c}\text { The number of } 3 \text { star and } \\
\text { more luxurious hotels }\end{array}$ & 6.08 & $6.63 \%$ \\
\hline $\mathrm{L}$ & Traffic Condition & Highway traffic mileage & 5.42 & $5.91 \%$ \\
\hline $\mathbf{M}$ & $\begin{array}{l}\text { The Degree of } \\
\text { Government } \\
\text { Attention }\end{array}$ & $\begin{array}{l}\text { Government financial } \\
\text { input }\end{array}$ & 7.26 & $7.92 \%$ \\
\hline $\mathbf{N}$ & $\begin{array}{l}\text { Urban Natural } \\
\text { Condition }\end{array}$ & $\begin{array}{l}\text { Per capita urban park } \\
\text { green area }\end{array}$ & 3.35 & $3.65 \%$ \\
\hline
\end{tabular}

the composite index is as follows:

$Z N=\alpha_{1} * K(A 1)+\alpha_{2} * K(B 1)+\cdots+\alpha_{14} * K(N 1)$. Wherein, is the indicator weight. The obtained results are listed in Table 2.

Table 2 reflects development levels of exhibition economy in the nine PRD cities and demonstrates comprehensive ranking of exhibition economy in these cities: Guangzhou, Shenzhen, Foshan, Dongguan, Huizhou, Zhuhai, Zhongshan, Zhaoqing and Jiangmen. Afterwards, these cities have been classified into three levels based on the ranking standards of the exhibition cities, which goes like follows: Guangzhou and Shenzhen; Foshan and Dongguan; Huizhou, Zhuzhou, Zhongshan, Zhaoqing and Jiangmen. The specific results are shown in Table 3. 
Table 2. Function indexes of cities in the PRD region.

\begin{tabular}{lccccccccc}
\hline & Guangzhou & Shenzhen & Zhuhai & Foshan & Zhongshan & Huizhou & Dongguan & Zhaoqing & Jiangmen \\
\hline K(A) & 3.00 & 1.00 & 0.00 & 3.00 & 0.00 & 0.50 & 1.50 & 0.00 & 0.00 \\
K(B) & 5.12 & 1.16 & 0.00 & 1.18 & 0.00 & 0.24 & 1.31 & 0.00 & 0.00 \\
K(C) & 5.64 & 1.04 & 0.05 & 0.23 & 0.77 & 0.35 & 0.70 & 0.21 & 0.00 \\
K(D) & 3.06 & 3.04 & 0.37 & 0.68 & 0.38 & 0.29 & 0.67 & 0.22 & 0.30 \\
K(E) & 3.00 & 2.00 & 1.00 & 1.00 & 1.00 & 0.00 & 1.00 & 0.00 & 0.00 \\
K(F) & 2.88 & 4.43 & 0.30 & 0.33 & 0.18 & 0.11 & 0.61 & 0.06 & 0.09 \\
K(G) & 2.07 & 1.74 & 0.25 & 1.14 & 0.49 & 0.73 & 1.26 & 0.62 & 0.69 \\
K(H) & 5.71 & 0.96 & 0.46 & 0.39 & 0.14 & 0.26 & 0.54 & 0.10 & 0.43 \\
K(I) & 2.32 & 2.21 & 0.83 & 0.51 & 0.41 & 0.77 & 0.77 & 0.46 & 0.71 \\
K(J) & 2.62 & 2.53 & 0.29 & 1.16 & 0.44 & 0.45 & 0.91 & 0.28 & 0.04 \\
K(P) & 2.91 & 1.75 & 1.10 & 0.85 & 0.29 & 0.73 & 0.82 & 0.21 & 0.34 \\
K(L) & 1.33 & 0.23 & 0.21 & 0.75 & 0.37 & 1.92 & 0.74 & 2.02 & 1.43 \\
K(M) & 2.14 & 1.87 & 0.67 & 1.36 & 0.48 & 0.77 & 0.71 & 0.50 & 0.51 \\
K(N) & 1.18 & 0.91 & 1.05 & 0.79 & 0.99 & 0.96 & 1.04 & 1.12 & 0.96 \\
K(Z) & 3.24 & 1.82 & 0.42 & 1.03 & 0.41 & 0.51 & 0.92 & 0.33 & 0.29 \\
\hline
\end{tabular}

Table 3. Ranking of exhibition cities in the PRD region.

\begin{tabular}{ccc}
\hline Urban Hierarchy about Exhibition Industry & Division Standard & Exhibition Urban \\
\hline level 1 exhibition cities & $\mathrm{K}(\mathrm{Z}) \geq 1.2$ & Guangzhou, Shenzhen \\
level 2 exhibition cities & $0.8 \leq \mathrm{K}(\mathrm{Z}) \leq 1.2$ & Foshan, Dongguan \\
level 3 exhibition cities & $\mathrm{K}(\mathrm{Z}) \leq 1.2$ & Huizhou, Zhuhai, Zhongshan, Zhaoqing, Jiangmen \\
\hline
\end{tabular}

\section{Empirical Analysis of Synergies of Exhibition Economy in the PRD Urban Agglomerations}

\subsection{Calculation of Synergy Potential of Exhibition Economy in Urban Agglomerations}

When it comes to the researches of the economic development of exhibition, it is inevitable to calculate the synergy potential of exhibition economy in urban agglomerations. Gravity models are physics models. They have been widely applied to economics, management science and other social sciences because of their simple structures. This research modifies gravity models in accordance with the distance-decay theory and adopts the improved models to calculate synergy potential of exhibition economy and hence to better reflect the synergy potential of exhibition economy. The models represent the distance between two cities with temporal distance and represent the scale of exhibition economy with the mean value of the number of exhibition halls, exhibition area, number of practitioners in the wholesale and retail industry, number of exhibition organizers, exhibition and business, passenger person-kilometers, tourism, urban economic level, 
number of hotels, resident population, transportation, government attention, urban natural environment and number of exhibitions in one city. The calculation formula is described below: $F_{x y}=\frac{T_{x} T_{y}}{D_{x y}^{2}}$.

Wherein, $F_{x y}$ on behalf of $X$ city and $Y$ city exhibition economy coordinated development potential value of the size; $T_{\chi}$ represents the total development level of exhibition economy in $X ; T_{y}$ represents the comprehensive development level of exhibition economy in $Y ; D_{x y}^{2}$ reflects transport accessibility between two cities.

Based on the exhibition economy in monomer cities in the PRD urban agglomerations, the gravity models are applied to researches on synergetic development of exhibition economy between the PRD cities. The gravity models are as follows:

Wherein, $F_{x y}$ represents the synergy potential of exhibition economy in $X$ and $Y ; T_{x}$ represents the total development level of exhibition economy in the PRD urban agglomerations; $T_{y}$ represents the total development level of exhibition economy in $Y ; D_{x y}^{2}$ reflects transport accessibility between two cities. (The transport accessibility is represented with the temporal distance between two cities.)

Table 4 demonstrates transport accessibility between the PRD cities, according to which, it has been revealed that in the table that the transport accessibility ranges from 0.8 to 3.6 hours. According to the gravity models, synergetic development of exhibition economy between cities is proportional to the comprehensive development level of exhibition economy and inversely proportional to the transport accessibility between cities. Therefore, it is an effective way to promote the comprehensive competiveness of exhibition economy and also the transport coverage between cities. Table 5 and Figure 1 present the synergy potential indexes of exhibition economy between the eight PRD cities. Based on potential analysis, it is feasible to present directive policy suggestions on the synergetic development of exhibition economy in the PRD urban agglomerations.

\subsection{Calculation and Analysis of Synergy Potential of Exhibition Economy}

With reference to the macroeconomic development strategy adopted by China, Guangdong Province develops a national strategy for regional integration and synergetic development of the PRD urban agglomerations, which stimulates the PRD cities to cooperate with each other more frequently in economy and established three small-scale economic circles, namely the Guang-Fo-Zhao Economic Circle, Shenzhen-Dongguan-Huizhou Economic Circle and Zhuhai-Zhongshan-Jiangmen Economic Circle. The calculation of synergy potential of exhibition economy also verifies the three small-scale economic circles, which is specifically manifested as follows:

A) Guang-Fo-Zhao Economic Circle: Guangzhou, which serves as a first-tier exhibition city and the center of Guang-Fo-Zhao Economic Circle, is 
Table 4. Transport accessibility between the PRD Cities.

\begin{tabular}{|c|c|c|c|c|c|c|c|c|c|}
\hline & Guangzhou & Shenzhen & Zhuhai & Foshan & Zhongshan & Huizhou & Dongguan & Zhaoqing & Jiangmen \\
\hline Guangzhou & 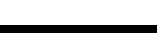 & 2.2 & 2.2 & 0.9 & 1.8 & 2.2 & 1.3 & 1.8 & 1.25 \\
\hline Shenzhen & 2.2 & . & 2.8 & 2.5 & 2.3 & 1.7 & 1.4 & 3.4 & 1.93 \\
\hline Zhuhai & 2.2 & 2.8 & & 2.2 & 1.2 & 3.1 & 2.2 & 2.8 & 1.3 \\
\hline Foshan & 0.9 & 2.5 & 2.2 & & 1.6 & 2.6 & 1.8 & 1.6 & 1.05 \\
\hline Zhongshan & 1.8 & 2.3 & 1.2 & 1.6 & & 2.8 & 1.8 & 2.4 & 0.97 \\
\hline Huizhou & 2.2 & 1.7 & 3.1 & 2.6 & 2.8 & & 1.7 & 3.6 & 2.4 \\
\hline Dongguan & 1.3 & 1.4 & 2.2 & 1.8 & 1.8 & 1.7 & & 2.7 & 1.65 \\
\hline Zhaoqing & 1.8 & 3.4 & 2.8 & 1.6 & 2.4 & 3.6 & 2.7 & & 1.63 \\
\hline Jiangmen & 1.25 & 1.93 & 1.3 & 1.05 & 0.97 & 2.4 & 1.65 & 1.63 & \\
\hline
\end{tabular}

Table 5. Synergy potential index of exhibition economy in the PRD Urban Agglomerations.

\begin{tabular}{|c|c|c|c|c|c|c|c|c|c|}
\hline & Guangzhou & Shenzhen & Zhuhai & Foshan & Zhongshan & Huizhou & Dongguan & Zhaoqing & Jiangmen \\
\hline Guangzhou & & 1580 & 355 & 5545 & 586 & 891 & 2173 & 1163 & 2051 \\
\hline Shenzhen & 1580 & 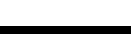 & 171 & 564 & 281 & 1171 & 1470 & 256 & 675 \\
\hline Zhuhai & 355 & 171 & 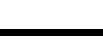 & 163 & 231 & 79 & 133 & 84 & 332 \\
\hline Foshan & 5545 & 564 & 163 & & 342 & 294 & 522 & 678 & 1340 \\
\hline Zhongshan & 586 & 281 & 231 & 342 & & 107 & 221 & 127 & 663 \\
\hline Huizhou & 891 & 1171 & 79 & 294 & 107 & & 562 & 129 & 246 \\
\hline Dongguan & 2173 & 1470 & 133 & 522 & 221 & 562 & & 195 & 444 \\
\hline Zhaoqing & 1163 & 256 & 84 & 678 & 127 & 129 & 195 & & 466 \\
\hline Jiangmen & 2051 & 675 & 332 & 1340 & 663 & 246 & 444 & 466 & \\
\hline
\end{tabular}

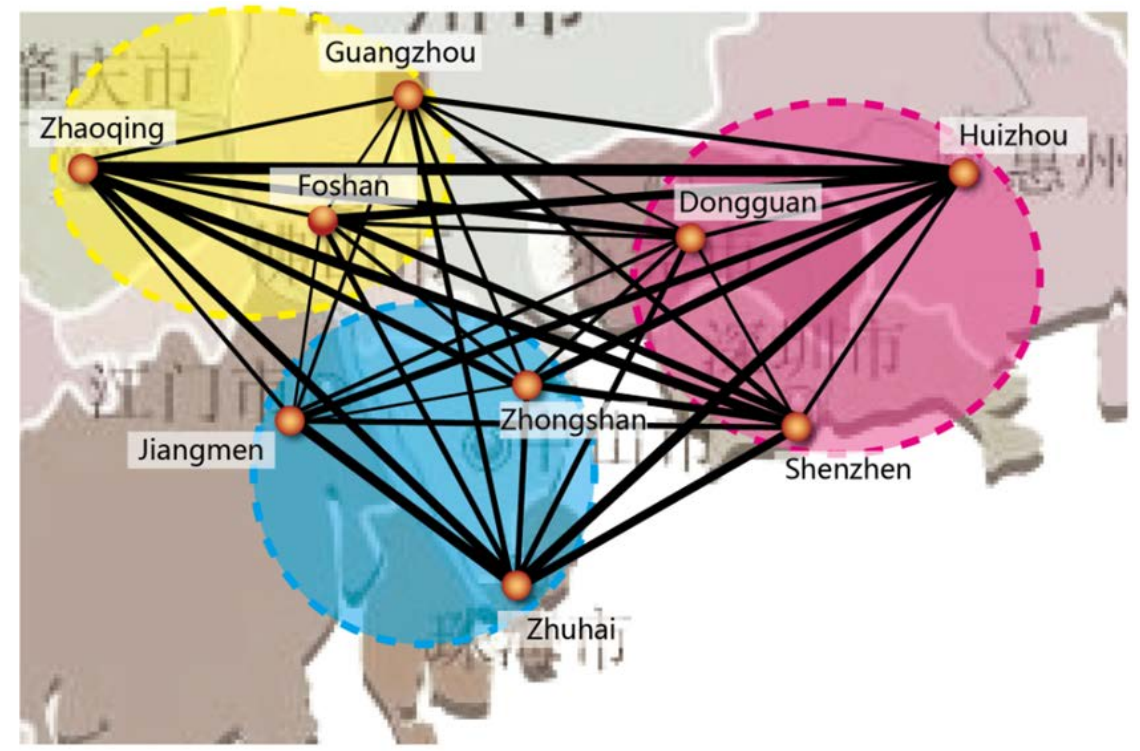

Figure 1. Pearl river delta city convention and exhibition economic cooperation relationships. 
closely related with first-tier cities, second-tier cities and some third-tier cities in the PRD region. The synergy index of exhibition economy between Guangzhou and Foshan is 5545, which is significantly greater than that between Guangzhou and Shenzhen (1580). A great step has been made in 2009, when the initiative of assimilating Guangzhou and Foshan was promoted. The two cities have realized integration in environmental protection systems, working systems, traffic contact systems and public service systems, and strengthened synergetic development to a certain extent by virtue of cooperation. In addition, the synergy index of exhibition economy between Guangzhou and Zhaoqing is 1163, indicating that these two cities cooperated closely with each other in exhibition industry. Since the presentation of the development planning of integrating Guangzhou, Foshan and Zhaoqing, these three cities mainly adopted a development path marching toward integrated economy by enhancing the cooperation between each other and the establishment of Guang-Fo-Zhao Synergetic Circle centered on the first-tier exhibition city Guangzhou.

B) Shenzhen-Dongguan-Huizhou Economic Circle: the synergy index of exhibition economy between Shenzhen and Dongguan is 1470 while that of between Shenzhen and Huizhou is 1171 . Both are significantly greater than that between Shenzhen and other cities. Shenzhen transformed its industries since the 1990s. Many enterprises in Shenzhen have migrated to Dongguan. Because of this, there were increased calls for the integration of Shenzhen and Donggugan. In recent years, lots of policies have been introduced to promote the integration of the two cities. For example, Shenzhen enterprises can enjoy similar preferential policies and service facilities when they establish factories in Dongguan. In this case, the two cities achieve a win-win situation. This certainly promotes exhibition exchanges and cooperation and improves synergetic development of exhibition economy between the two cities. In 2008, the Outlines for Reform and Development Planning of Pearl River Delta Region were issued to promote the construction of the Shenzhen-Dongguan-Huizhou Economic Circle, aiming to enhance the political, economic and cultural cooperation between the three cities and hence to gradually realize the information and economic integration. When the three cities strove to realize integrated development of economy, culture and transportation, the Shenzhen-Dongguan-Huizhou Economic Circle which is centered on Shenzhen was established.

C) Zhuhai-Zhongshan-Jiangmen Economic Circle: synergy indexes between third-tier exhibition cities in the PRD region are extremely low. For example, the synergy index between Huizhou and Zhuhai is 79 and that between Zhaoqing and Zhuhai is 84 . Synergy indexes between individual third-tier exhibition cities and first-tier or second-tier cities exceed 1000. Since Zhuhai, Zhongshan and Jiangmen belong to third-tier exhibition cities, they have low synergy indexes. In addition to Guangzhou, Zhuhai is highly synergetic with Jiangmen and Zhongshan, with the synergy index of 332 and 231 respectively. Considering the poor economic strength and synergetic development of these three cities, the Zhuhai-Zhongshan-Jiangmen Economic Circle has been estab- 
lished.

D) Synergetic Development of Exhibition Economy in the PRD Urban Agglomerations: back in 2014 when the economic integration strategy was implemented, the Department of Transportation actively responded to the integration strategy, vigorously promoted the development of transportation integration in the PRD region and invested a total of 548,600,000 RMB in transportation infrastructure. These various cities cooperated with each other and took multiple measures to push forward highway construction. Under the joint efforts of multiple parties, all the tasks of the Outlines were successfully completed, including the Hong Kong-Zhuhai-Macau Bridge and the Shenzhen-Zhuhai Bridge. The PRD highway was 3533 kilometers in length, which already exceeds the annual objectives. The PRD region invested heavily in transportation, thereby making transportation between the PRD cities more convenient and forming half an hour economic circles and one hour economic circles. Even under convenient transportation, exhibition economy between the various cities still has enclave effects. The two first-tier exhibition cities (Guangzhou and Shenzhen) and the two second-tier exhibition cities (Foshan and Dongguan) have maintained a good momentum of development and formed Guang-Fo-Zhao Economic Circle centered on Shenzhen, Shenzhen-Dongguan-Huizhou Economic Circle centered on Shenzhen and Zhuhai-Zhongshan-Jiangmen Economic Circle centered on Zhujiang. However, the three economic circles are poorly synergetic. The synergy index between Guangzhou and Zhuhai is 353 and that between Zhuhai and Shenzhen is 171, indicating that the PRD urban agglomerations still have great potential for further improvement.

\section{Conclusion}

Synergetic development serves as an important driving force for economic growth in urban agglomerations while the exhibition industry has strong industrial relevance and plays an important adhesive role in the coordinated development of urban areas. This paper takes the PRD urban agglomeration as the research object, constructs micro-data based evaluation indicator systems for exhibition economy in the eight major PRD cities and adopts improved gravity models to calculate and analyze synergetic development potential of exhibition economy between cities. The research results show that, number of exhibition halls, exhibition scale and exhibition frequency, all of which have a weight of above 9\%, are three important indexes to reflect the development of a city's exhibition industry. In the development process of the national-level PRD urban agglomeration, three small-scale exhibition economic circles came into being, namely, Guang-Fo-Zhao Economic Circle, Shenzhen-Dongguan-Huizhou Economic Circle and Zhuhai-Zhongshan-Jiangmen Economic Circle. Wherein, Guang-Fo-Zhao Economic Circle is centered on Guangzhou while Shenzhen-Dongguan-Huizhou Economic Circle and Zhuhai-Zhongshan-Jiangmen Economic Circle are centered on Shenzhen. 


\section{Policy Recommendations}

Based on the research results, the following policy recommendations are proposed to better promote the synergetic development of exhibition economy in the PRD urban agglomeration.

\subsection{Establish Management Departments for Synergetic Development of Exhibition Economy in the PRD Urban Agglomeration}

In terms of the exhibition industry in the PRD urban agglomeration, the three exhibition economic circles co-exist. However, seldom do they cooperate with each other on exhibition or seek opportunities for common development. Therefore, it is necessary to establish management departments for exhibition development, uniform instructions on exhibition development, strengthen cooperation and exchanges on exhibition, avoid homogeneous exhibitions and develop exhibition economy in the PRD urban agglomeration in a planned way.

\subsection{Rationalize the Allocation of Resources and Realize Synergetic Development in the PRD Urban Agglomeration}

In 2015, there were 21 exhibition halls being built, involving a total area of $1,868,200 \mathrm{~m}^{2}$ (628,000 $\mathrm{m}^{2}$ in Guangdong Province). Although the number of exhibitions in the PRD urban agglomeration has increased rapidly, the utilization rate of exhibition halls is merely $30 \%$, which may cause an oversupply of exhibition halls in the future. Therefore, the PRD urban agglomeration should take immediate measures to guard against possible risks. It should seize the integration opportunities to vigorously promote economic integration and make full use of existing exhibition resources to maximize the exhibition benefits.

\subsection{Positively Explore Features of Each City and Emphasize the Construction of Exhibition Brands}

To develop the exhibition industry successfully, it is important to fully master characteristics of the exhibition industry, seek advantages of cities and build characteristic exhibition brands. If cities with poor exhibition economy hold exhibitions blindly, rather than seek their own characteristics, the exhibitions shall be homogeneous, eventually depriving cities of their advantages and influencing the development of central exhibition cities. Therefore, it is of great importance to explore regional characteristics, build characteristic exhibition brands in accordance with featured products and seek refinement. It is inadvisable to hold exhibitions blindly to promote exhibition economy, since cities will lose their advantages in the long-term development and get more kicks than halfpence in that case.

\section{Acknowledgements}

The Research Cultivation and Innovation Fund Youth Project of Jinan University: "Human Capital Heterogeneity, Mobility and Regional Economic Devel- 
opment", project number: 11617368. Shenzhen Maker Space: Jinan University Shenzhen Campus "Yanhan Maker Space", 2015-2016, project number: CKSJS2015093014572968.

\section{References}

[1] Allen, J., et al. (2011) Festival \& Special Event Management. John Wiley \& Sons Australia, Ltd., Milton, QLD.

[2] Chacko, H.E. and Schaffer, J.D. (1993) The Evolution of a Festival. Tourism Management, 14, 475-482. https://doi.org/10.1016/0261-5177(93)90100-Y

[3] Teigland, J. (1999) Mega-Events and Impacts on Tourism; The Predictions and Realities of the Lillehammer Olympics. Impact Assessment and Project Appraisal, 17, 305-317. https://doi.org/10.3152/147154699781767738

[4] Wang, B.L. (2003) Discussion on the Development Mode of MICE Tourism. Tourism Tribune, 18, 8-12.

[5] Chen, L.S. (2005) Exhibition Economy. Fudan Press, Shanghai, 30-33.

[6] He, J.Y. (2004) Discussion on the Conceptual \& Connotation of MICE Tourism. Journal of Harbin University of Commerce: Social Science Edition, No. 3, 98-99.

[7] Zhang, J. (2008) Research on the Development of Exhibition Industry Base the Yangtze River Delta as Platform. Master Thesis, Shanghai Jiao Tong University, Shanghai.

[8] Hu, P. and Yang, J. (2006) The Empirical Study on the Pulling Effect of Exhibition Industry Economy-A Case Study of Shanghai New International Expo Center. Tourism Tribune, 21, 81-85.

[9] Li, L. and Ji, J.H. (2007) Research of Method on Spatial Definition of Metropolitan. Statistics and Decision, No. 2, 109.

[10] Sun, Q. (2008) Research on the Integration of Convention and Exhibition Industry in Yangtze River Delta under the Opportunity of World Expo. Master Thesis, Shanghai Normal University, Shanghai.

[11] Zhang, J. (2005) The Analysis of the Exhibition Economy in the Pearl River Dalta. Master Thesis, Jinan University, Guangzhou.

[12] Huang, Q.B. (2009) A Quantitative Analysis of the Impact of Hangzhou Exhibition Industry and Major Related Industries. Market Modernization, No. 3, 264-265.

[13] Tang, Y. (2011) Regional Governance and Cooperation in German Metropolitan Areas. China Architecture \& Building Press, Beijing, 1-20.

[14] Jiang, M.Q. (2013) Reacquaint of Urban Agglomeration and Its Related Concepts. Urban Studies, 20, 30-35.

[15] Cheng, Y.H. and Luo, J.J. (2013) A Review of the Research on Coordinated Development of Urban Agglomeration. Urban Problems, No. 1, 26-31.

[16] Liu, W. (2014) Economic Integration of Beijing, Tianjin and Hebei and the Development of Exhibition Economy. Advantages and Docking of Langfang Area High-End Urban Forum Proceedings, Beijing, April 2014, 53-56. 